\title{
Analisis Kinerja Koperasi Melalui Pemeringkatan Koperasi Berdasarkan Permenkop No. 21/Per/M.KUKM/IX/2015
}

\author{
Srikalimah $^{1}$, Endah Kurniawati ${ }^{2}$ \\ ${ }^{1,2}$ Universitas Islam Kadiri \\ srikalimah@uniska-kadiri.ac.id*, endahkurniawati@uniska-kediri.ac.id
}

*Penulis Korespondensi

Diajukan : 1 September 2021

Disetujui : 3 Oktober 2021

Dipublikasi : 3 Oktober 2021

\begin{abstract}
The rating is one of the performance assessments of cooperatives. To find out the ranking of the Multipurpose Joint Venture Cooperative in 2020 is the purpose of this study. The assessment is based on PERMENKOP and SMEs of the Republic of Indonesia Number 21/Per/M.KUKM/IX/2015 concerning Rating of Cooperatives. This research is evaluation research. The types of data used in this study are qualitative and quantitative data, the data sources in this study are primary and secondary. The subjects of this research are the administrators, supervisors, members of KSU Statuegilan. The object of this research is the ranking result of KSU Statuegilan. Collecting data using interview techniques, documentation and questionnaires. The assessment of KSU Sculpture uses ranking as an Evaluation Model. This study shows the results that: (I) In terms of the institutional aspect of the cooperative obtained a score of 720, (II) In terms of the business aspect, the cooperative obtained a score of 112.5 (III) In terms of the financial aspect of the cooperative obtained a score of 197.5, (IV) In terms of Aspects of the benefits of cooperatives to the community get a score of 11. From the accumulated results, a performance assessment score is obtained in terms of the five aspects that have been carried out, KSU Statuegilan obtained a score of 1,076. The score is in the range of scores of 1,000 to 1,200 so that KSU Statuegilan is included as a cooperative with "Berkualitas" qualifications with $\boldsymbol{A A B}$ predicate.
\end{abstract}

Keywords : cooperative performance, cooperative ranking, KSU Statuegilan

\section{PENDAHULUAN}

Sokoguru perekonomian di Indonesia adalah koperasi. Sebagai sokoguru dalam menghadapi persaingan serta tantangan perekonomian saat ini terlebih di masa pandemic covid 19 harus dihadapi. Dalam menghadapi hal tersebut peran semua unsur dari koperasi itu sendiri mulai dari pengurus, pengawas, pengelola sampai dengan anggota diharapkan untuk selalu proaktif, memiliki inovasi dan jiwa kewirakoperasian dalam menghadapi perekonomian saat ini dan menghadapi kemungkinan yang terjadi di masa yang akan datang. Untuk itu harus didasari semangat dan motivasi yang tinggi dan selalu berpegang teguh terhadap asas dan prinsip-prinsip koperasi.

Tujuan koperasi dibentuk adalah agar kesejahteraan anggota meningkatkan. Tatanan perekonomian nasional yaitu koperasi merupakan bagian yang menjadi satu kesatuan tidak terpisahkan dari yang demokratis dan berkeadilan. Untuk memperbaiki kualitas kinerja koperasi diperlukan suatu pengukuran terhadap kinerja koperasi itu sendiri. Variabel kinerja koperasi secara umum dapat diukur agar dapat melihat pertumbuhan (growth) dan perkembangan koperasi di Indonesia yang terdiri dari aspek kelembagaan (jumlah koperasi per provinsi, jumlah koperasi per jenis/kelompok koperasi, jumlah koperasi aktif dan nonaktif), keanggotaan, volume usaha, aset dan sisa hasil usaha (Arifin \& Halomoan, 2001).

Pemeringkatan koperasi merupakan suatu sistem penilaian hasil pemberdayaan koperasi yang saat ini diterapkan oleh pemerintah adalah dengan melakukan pemeringkatan koperasi. 
Pemeringkatan koperasi merupakan kegiatan penilaian kinerja koperasi dengan berpedoman atas pelaksanaan yang bersendikan pada nilai-nilai dan prinsip-prinsip koperasi (Rahman, 2018). Tujuan umum dilakukannya penilaian kinerja koperasi melalui metode pemeringkatan koperasi yaitu untuk mengidentifikasi masing-masing fungsi pada koperasi sehingga apa yang diharapkan dapat berjalan sesuai dengan yang diharapkan.

Pengukuran kinerja koperasi di bawah Dinas Koperasi selama ini masih sebatas menggunakan pengukuran kinerja keuangan yang pengukurannya sebatas dari laporan keuangan dengan menggunakan analisa rasio keuangan yaitu rentabilitas, likuiditas, dan solvabilitas. Terdapat beberapa kelemahan dalam pengukuran kinerja tersebut sehingga diperlukan pengukuran yang menyeluruh, yaitu pengukuran kinerja yang tidak hanya mengukur kinerja keuangan tetapi mampu menggambarkan kondisi koperasi secara lengkap, jelas dan akurat terutama menyangkut sumber daya manusia yang diintegrasikan dalam perencanaan baik organisasi maupun usaha. Konsep pengukuran kinerja yang menyeluruh memberikan manfaat sebagai acuan dalam penelitian kinerja keuangan yang lebih akurat efektif dan efisien.

Koperasi dapat dikatakan berkualitas apabila koperasi memiliki kinerja baik dalam bidang kelembagaan, usaha, keuangan sekaligus manfaat bagi seluruh anggota koperasi yang memiliki badan hukum aktif dan badan usaha yang memiliki ciri prinsip-prinsip kohesivitas dan partisipasi anggota yang kuat dengan memiliki kinerja usaha yang semakin sehat serta memiliki orientasi kepada usaha anggota dan memiliki kepedulian sosial (Permenkop No. 21, 2015). Prioritas pembangunan saat ini adalah dengan pendekatan sumber daya manusia. Bukan berarti pemerintah tidak ikut campur tangan, namun dalam rangka menciptakan iklim kondusif kemandirian koperasi sangat diperlukan untuk memberikan dorongan serta untuk menggalang partisipasi positif berbagai pihak yang berhubungan dengan pembangunan koperasi. Guna pemberdayaan koperasi tersebut, melalui Kementerian Koperasi dan UKM pemerintah telah berupaya untuk memperoleh dukungan agar data tersedia yang akurat dan aktual yang memiliki gambaran gambar kondisi koperasi yang sebenarnya terjadi dilapangan. Dengan bertambahnya jumlah koperasi terus sehingga mampu menyerap tenaga kerja dalam jumlah yang signifikan sehingga akan mengurangi pengangguran dan koperasi berperan dalam pengentasan kemiskinan masyarakat. Berdasarkan data statistik koperasi yang dikeluarkan oleh Badan Pusat Statistik (2021), di Indonesia jumlah koperasi pada tahun 2018 sebanyak 126.343 unit pada tahun 2019 sebanyak 123.048 unit dan pada tahun 2020 meningkat menjadi 127.124 unit. Sedangkan data yang diperoleh dari Kementerian Koperasi dan UKM jumlah koperasi di Indonesia tergolong tinggi tercatat sebanyak 127.124 pada akhir tahun 31 Desember 2020 yang aktif / pernah tercatat sebagai koperasi aktif dan memiliki sertifikat NIK sebanyak 38.865 , tetapi tidak sedikit juga koperasi yang kegiatannya pasif. Jika secara kelembagaan dan usaha telah melaksanakan Rapat Anggota Tahunan (RAT) minimal sekali dalam tiga tahun terakhir koperasi dianggap aktif. Hingga akhir 2020, total anggota 25.098.807 orang (Kemenkop, 2021).

Di sejumlah daerah, perkembangan koperasi cukup signifikan, dilihat dari peningkatan jumlah anggota, permodalan, kinerja keuangan, penyerapan tenaga kerja, volume usaha, maupun perolehan sisa hasil usaha (SHU). Dengan perkembangan tersebut dapat dikatakan bahwa koperasi semakin merakyat menjadi suatu unit usaha yang memiliki peran cukup besar bagi sejumlah besar penduduk. Permodalan yang meningkat dalam koperasi merupakan wujud bergeraknya bisnis koperasi menuju penguatan usaha untuk bersaing secara terbuka dalam ekonomi nasional menuju efisiensi (Rahman, 2018). Indikasi peningkatan kinerja dan produktivitas bisnis merupakan peningkatan pada output/volume usaha dan SHU menjadi salah satu kontribusi pada peningkatan income masyarakat. Koperasi dikatakan berkulaitas jika koperasi mampu menjalankan serta melaksanakan fungsi dan peran yang diharapkan secara berkelanjutan, salah satunya yaitu dapat memberikan suatu pelayanan yang bermanfaat bagi anggota koperasi serta mempertanggungjawabkan semua kegiatan koperasi dalam Rapat Anggota Tahunan (RAT) tiap tahunnya.

Untuk mengetahui kinerja koperasi dalam satu periode tertentu dan menetapkan peringkat kualifikasi koperasi, pemeringkatan koperasi penting untuk dilakukan supaya mendorong koperasi agar tetap menerapkan prinsip-prinsip koperasi dan kaidah bisnis yang sehat. Pemeringkatan koperasi merefleksikan tingkat kesehatan seluruh unsur yang ada, serta digunakan untuk meningkatkan daya dukung dan daya saing bisnis. Oleh sebab itu, peneliti melakukan kegiatan pemeringkatan koperasi pada KSU Patunggilan Mojokerto untuk mengetahui peringkat koperasi 
tersebut apakah berkualitas atau tidak dengan menggunakan pemeringkatan koperasi. Dengan kegiatan pemeringkatan tersebut diharapkan agar koperasi sebagai suatu badan usaha yang memiliki kemampuan untuk meningkatkan kesejahteraan para anggota koperasi pada khususnya dan bagi luar anggota koperasi atau masyarakat pada umumnya sebagai gambaran dari peringkat kualifikasi koperasi tersebut.

\section{STUDI LITERATUR}

Koperasi merupakan suatu bentuk organisasi yang memiliki badan hukum yang dapat didirikan oleh orang perseorangan atau yang memiliki badan hukum yaitu Koperasi, dimana terdapat pemisahan kekayaan para anggotanya sebagai modal dalam menjalankan suatu usaha, yang memenuhi aspirasi dan kebutuhan bersama di bidang ekonomi, sosial, dan budaya sesuai dengan nilai dan prinsip Koperasi (Kemenkop, 2012). Sejarah mencatat bahwa awal mula didirikan koperasi memiliki landasan Pancasila dan Undang Undang Dasar 1945. Maksudnya, dalam menjalankan usahanya koperasi harus tunduk sesuai dengan aturan yang tertuang dalam Pancasila dan UUD '45. Azas koperasi adalah kekeluargaan. Maksud dari pernyataan tersebut adalah koperasi memiliki tujuan tidak hanya menguntungkan satu orang saja, tetapi untuk memperoleh keuntungan bersama. Hal tersebut yang membedakan koperasi dengan badan usaha lainnya.

Kinerja merupakan suatu kondisi dimana para individu dan para organisasi untuk mencapai suatu tujuan pada organisasi secara efektif dan efisien, (Boove dkk, 1990:10) dalam (Asdhiwitanto et al., 2015). Manfaat penelitian kinerja, menghadapi persaingan yang semakin kompetitif, perusahaan dituntut untuk dapat bersaing dengan dan ini ditunjang oleh kinerja perusahaan. Penilaian kinerja berguna untuk mengetahui efisiensi dan profitabilitas operasi serta menimbang seberapa efektif penggunaan sumber daya perusahaan (Helfert, 1996:70).

Suyadi Prawirosentono (1999: 195) dalam (Widagdo, 2013) menjelaskan dalam mengukur kinerja organisasi dan kinerja perorangan memerlukan standar kinerja terlebih dahulu. Kriteria standar kinerja harus jelas dan objektif. Standar kinerja yang telah ditentukan, digunakan untuk membandingkan kinerja tahun sebelumnya dengan kinerja sebenarnya. Dari hasil perbandingan kinerja yang sesuai dengan standar kinerja, akan menggambarkan bagaimana kinerja organisasi tersebut. Apabila ditemukan kinerja yang telah dilakukan lebih buruk dari standar kinerja, berarti diperlukan adanya umpan balik bagi organisasi untuk memperbaiki kinerjanya.

Pemeringkatan koperasi merupakan salah satu sistem penilaian hasil pemberdayaan koperasi yang saat ini diterapkan oleh pemerintah untuk mengukur kinerja koperasi. Pemeringkatan koperasi merupakan kegiatan penilaian kinerja koperasi dengan berpedoman atas pelaksanaan yang bersendikan pada nilai-nilai dan prinsip-prinsip koperasi (Rahman, 2018). Pemeringkatan Koperasi adalah suatu alat penilaian terhadap kondisi dan atau kinerja koperasi melalui sistem pengukuran secara obyektif dan transparan terhadap koperasi (Menkop, 2015). Adapun tujuan umum dari kegiatan pemeringkatan koperasi adalah mengidentifikasi kinerja koperasi pada masing-masing fungsi sehingga dapat berjalan sesuai dengan yang digariskan(Rahman, 2018).

Pada penelitian (Bagus et al., 2019) hasil penelitian KSU Nirmala bahwa kinerja tahun 2017 berdasarkan PerMenKop dan UMKM No. 06/Per/M.KUKM/III/2008 tentang Pedoman Pemeringkatan Koperasi menunjukkan ada 5 aspek untuk pemeringkatan koperasi yaitu aspek badan usaha aktif, kinerja usaha, kohesivitas dan partisipasi anggota, orientasi kepada pelayanan anggota, pelayanan kepada masyarakat dan kontribusi terhadap pembangunan daerah. Sedangkan pada penelitian ini mengacu pada PERMENKOP dan UKM Republik Indonesia Nomor 21/Per/M.KUKM/IX/2015 Tentang Pemeringkatan Koperasi dengan menggunakan 5 aspek yaitu aspek kelembagaan koperasi, usaha koperasi, keuangan koperasi, dan aspek manfaat koperasi terhadap masyarakat. Hal ini yang melatarbelakangi penelitian ini.

Adapun tujuan dari pemeringkatan koperasi melalui Peraturan Menteri Koperasi dan Usaha Kecil dan Menengah Republik Indonesia Nomor 21/Per/M.KUKM/IX/2015 Tentang Pemeringkatan Koperasi, yaitu

1. Mengetahui tingkat kinerja koperasi dalam suatu periode tertentu;

2. Menunjukkan keberhasilan dan eksistensi koperasi kepada pihak-pihak yang berkepentingan;

3. Tumbuhnya kesadaran koperasi akan pentingnya hasil pemeringkatan koperasi; 
4. Meningkatnya kepercayaan anggota koperasi, masyarakat, mitra kerja dan pemangku kepentingan kepada koperasi.

Sistem pemeringkatan koperasi memiliki batasan yang jelas tentang kriteria dan indikator koperasi yang berkualitas, pendekatan penilaian sistem pemeringkatan bersifat input, proses, dan output. Pemeringkatan koperasi dilakukan oleh Lembaga Independen yang memiliki kompetensi dibidangnya serta telah diakreditasi sesuai Peraturan yang berlaku sebagai Lembaga Independen Pemeringkat Koperasi (LIPK) (Menkop, 2015). Indikator penilaian pemeringkatan ini agar dapat memberikan hasil yang menggambarkan secara utuh koperasi sebagai badan usaha dalam sistem pemeringkatan koperasi mencakup aspek-aspek, yaitu :

a. Aspek Kelembagaan Koperasi (Bobot 30), meliputi: 1) legalitas badan hukum; 2) partisipasi anggota; 3) alat kelengkapan organisasi koperasi; 4) program kerja, dan rencana strategis; 5) standar operasional prosedur; 6) standar operasional manajemen; 7) rapat anggota; 8) pendidikan dan pelatihan; 9) rasio peningkatan jumlah anggota; 10) penghargaan Koperasi 3 (tiga) tahun terakhir

b. Aspek Usaha Koperasi (Bobot 25), meliputi: 1) legalitas usaha; 2) keterikatan aktivitas usaha anggota dengan usaha anggota lain; 3) keterikatan usaha anggota dengan usaha koperasi; 4) peningkatan volume usaha; 5) peningkatan kapasitas produksi atau jasa; 6) peningkatan SHU

c. Aspek Keuangan Koperasi (Bobot 25), meliputi: 1) struktur permodalan; 2) kemampuan penyediaan dana untuk memenuhi kewajiban yang sudah jatuh tempo (tingkat liquiditas); 3) persentase pelunasan simpanan wajib; 4) total hutang jangka pendek terhadap aset; 5) kemampuan koperasi untuk memenuhi kewajibannya (Solvabilitas); 6) rasio laba bersih terhadap investasi (Return On Investment); 7) penambahan aset; 8) audit Kantor Akuntan Publik (KAP); 9) keberlanjutan usaha.

d. Aspek Manfaat Koperasi Terhadap Anggota (Bobot 10), meliputi: 1) peningkatan penghasilan anggota; 2) menawarkan barang dan jasa yang lebih murah; 3) menumbuhkan motif berusaha anggota; 4) menumbuhkan sikap jujur dan terbuka; 5) pemberian layanan koperasi diluar aktivitas usaha.

e. Aspek Manfaat Koperasi terhadap Masyarakat(Bobot 10), meliputi: 1) penyerapan tenaga kerja; 2) jumlah layanan koperasi yang dapat dinikmati masyarakat; 3) penurunan angka kemiskinan.

Tata Cara Penilaian Indikator dan Parameter Pemeringkatan Koperasi Penilaian pemeringkatan dinilai melalui Indikator dan Parameter yang dimiliki oleh koperasi. Metode penilainnya dengan menggunakan rata-rata bobot nilai, langkah-langkah tatacara penilaiannya adalah sebagai berikut:

1. Nilai Aspek $\mathrm{n}=($ Jumlah Nilai Parameter $\mathrm{x} \%$ Bobot Aspek $)$

Contoh : Nilai Aspek $1=($ Nilai Indikator1 $\times 30 \%)$

Nilai Asepk $2=($ Nilai Indikator1 $\times 25 \%)$

Nilai Aspek $3=($ Nilai Indikator $1 \times 25 \%)$

Nilai Asepk $4=($ Nilai Indikator1 $\times 10 \%)$

Nilai Asepk $5=($ Nilai Indikator1 $\times 10 \%)$

2. Hasil Penilaian Pemeringkatan $=($ Nilai Aspek 1+ Nilai Aspek 2+ Nilai Aspek 3+ Nilai Aspek 4+ Nilai Aspek 5

Penetapan Hasil Pemeringkatan Hasil pemeringkatan koperasi ditetapkan dalam 4 (empat) klasifikasi kualitas :

a. Koperasi dengan kualifikasi "Sangat Berkualitas", dengan predikat AAA, dengan jumlah penilaian diatas 1.200;

b. Koperasi dengan kualifikasi "Berkualitas", dengan predikat AAB, ", dengan jumlah penilaian 1.000 sampai dengan 1.200 ;

c. Koperasi dengan kualifikasi " Cukup Berkualitas", dengan predikat ABB, dengan jumlah penilaian 800 sampai dengan 999;

d. Koperasi dengan kualifikasi " Tidak Berkualitas", dengan predikat BBB, dengan jumlah penilaian kurang dari 799; 
Berdasarkan Peraturan Deputi Bidang Kelembagaan No. 04/Per/Dep.1/III/2018 tentang Kriteria dan Indikator Penilaian Pemeringkatan Koperasi, hasil pemeringkatan koperasi ditetapkan dalam 4 (empat) klasifikasi kualitas :

a. Koperasi dengan kualifikasi "Sangat Berkualitas", dengan predikat AAA, dengan jumlah penilaian diatas 1.200 ;

b. Koperasi dengan kualifikasi " Berkualitas", dengan predikat AAB, ", dengan jumlah penilaian 1.000 sampai dengan 1.200;

c. Koperasi dengan kualifikasi " Cukup Berkualitas", dengan predikat ABB, dengan jumlah penilaian 800 sampai dengan 999;

d. Koperasi dengan kualifikasi " Tidak Berkualitas”, dengan predikat BBB, dengan jumlah penilaian kurang dari 799

\section{Kerangka Penelitian}

Kerangka berpikir digambarkan dalam bagan penelitian sebagai berikut:

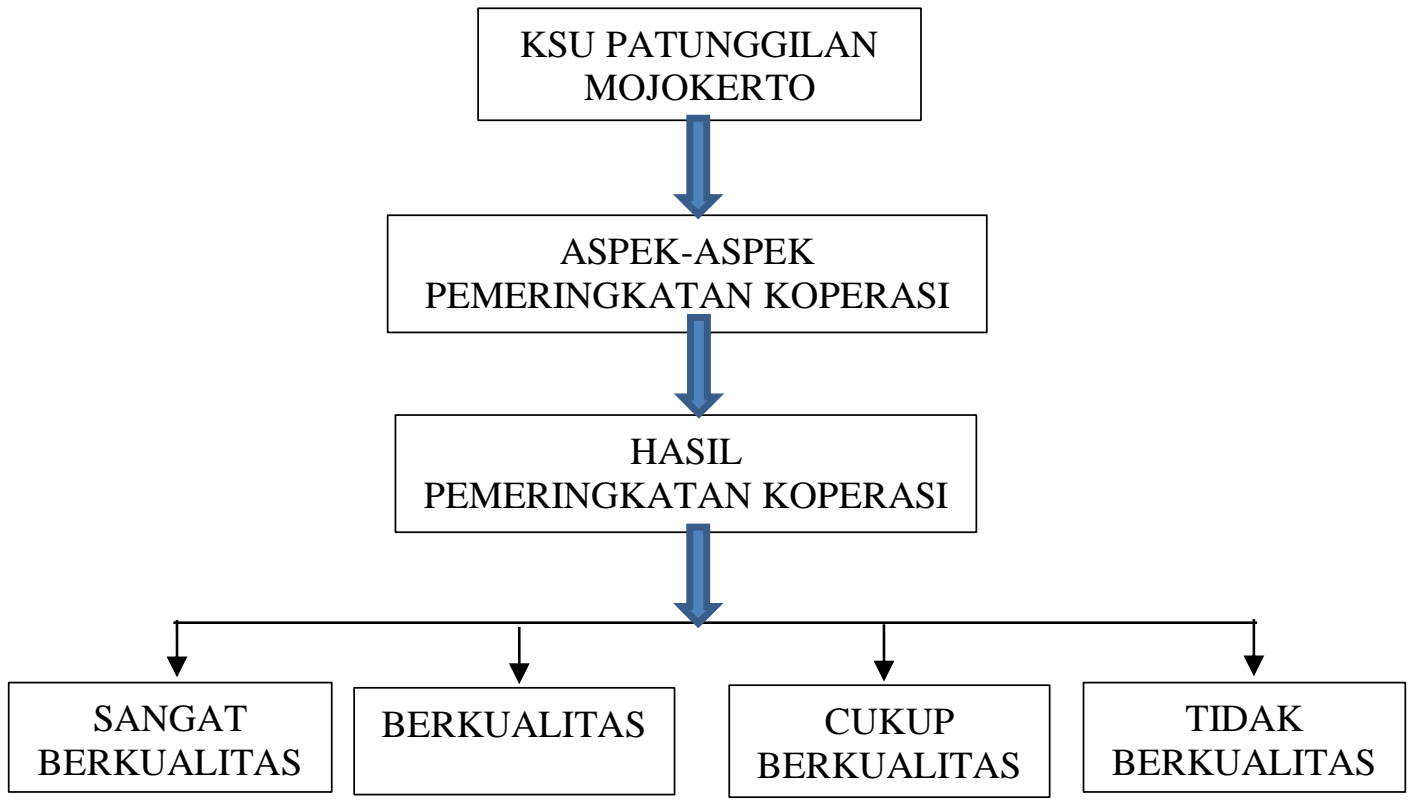

Gambar 1. Kerangka Pikir

Sumber : Data diolah peneliti, 2021

Pemeringkatan Koperasi Serba Usaha (KSU) Patunggilan dalam penelitian ini dilakukan untuk memperoleh gambaran kinerja dan peringkat kualifikasi KSU Patunggilan Tahun 2020 agar hasilnya dapat dijadikan referensi perbaikan serta pengembangan KSU Patunggilan selanjutnya. Kegiatan penilaian kinerja dengan pemeringkatan koperasi berpedoman pada aspek-aspek yang didasarkan Peraturan Menteri Koperasi dan UMKM NOMOR 21/Per/M.KUKM/IX/2015 tentang Pedoman Pemeringkatan Koperasi. Aspek-aspek tersebut yaitu aspek kelembagaan koperasi, aspek usaha koperasi, aspek keuangan koperasi, aspek manfaat koperasi terhadap anggota, dan aspek manfaat koperasi terhadap masyarakat. Hasil dari penilaian apek-aspek tersebut akan menunjukkan KSU Patunggilan ke dalam kualifikasi sangat berkualitas, berkualitas, cukup berkualitas, dan tidak berkualitas.

\section{METODE}

Penelitian ini menggunakan metode analisis deskriptif kuantitatif. Penelitian ini dapat digolongkan sebagai penelitian eksploratif dan evaluatif. Sifat penelitian ini ditujukan untuk menelaah perkembangan keragaan dan kinerja antara koperasi dan anggotanya. Focus penelitian untuk mengukur kinerja koperasi dengan metode pemeringkatan koperasi guna mendapatkan hasil koperasi sangat berkualitas, berkualitas, kurang berkualitas dan tidak berkualitas pada KSU 
Patunggilan Mojokerto sesuai dengan Peraturan Menteri Koperasi Dan Usaha Kecil Dan Menengah Republik Indonesia Nomor 21/Per/M.KUKM/IX/2015 Tentang Pemeringkatan Koperasi dan Peraturan Deputi Bidang Kelembagaan Kementerian Koperasi Dan Usaha Kecil Dan Menengah Nomor : 04/Per/Dep.1/III/2018 Tentang Kriteria Dan Indikator Penilaian Pemeringkatan Koperasi. Penelitian ini dilaksanakan pada KSU Patunggilan Mojokerto yang beralamat di Jl.Panggreman Lapangan 29 Mojokerto. Badan Hukum No. 518/65/BH/417-311/IX/2003 dan NIK No. : 3576020030203

Variabel yang dugunakan untuk menilai pemeringkatan koperasi sesuai dengan Peraturan Menteri Koperasi dan Usaha Kecil dan Menengah Republik Indonesia Nomor 21/Per/M.KUKM/IX/2015) Tentang Pemeringkatan Koperasi, meliputi aspek kelembagaan koperasi; aspek usaha koperasi; aspek keuangan koperasi; aspek manfaat koperasi terhadap anggota; dan aspek manfaat koperasi terhadap masyarakat.

\section{HASIL}

Kinerja KSU Patunggilan Ditinjau dari Aspek Kelembagaan Koperasi

Berdasarkan pedoman pemeringkatan koperasi apabila dinilai dari aspek kelembagaan koperasi KSU Patunggilan dapat dijelaskan dalam tabel berikut.

Tabel 1

Nilai dan Skor ditinjau dari Aspek Kelembagaan Koperasi

\begin{tabular}{|c|l|c|c|}
\hline No & \multicolumn{1}{|c|}{ Indikator } & \multicolumn{1}{|c|}{$\begin{array}{c}\text { Skor } \\
\text { maksimal }\end{array}$} & $\begin{array}{c}\text { Nilai } \\
(\mathrm{N})\end{array}$ \\
\hline 1 & Legalitas Badan Hukum & 500 & 500 \\
\hline 2 & $\begin{array}{l}\text { Partisipasi Anggota (Dalam Permodalan Atau } \\
\text { Bidang Usaha) }\end{array}$ & 200 & 200 \\
\hline 3 & Alat Kelengkapan Organisasi Koperasi & 200 & 200 \\
\hline 4 & Rencana Strategis (Renstra) & 300 & 200 \\
\hline 5 & Standar Operasional Prosedur (SOP) & 300 & 300 \\
\hline 6 & Standar Operasional Manajemen (SOM) & 300 & 300 \\
\hline 7 & $\begin{array}{l}\text { Rapat Anggota Pertanggungjawa Ban } \\
\text { Pengurus Dan Pengawas }\end{array}$ & 400 & 300 \\
\hline 8 & Pendidikan Dan Pelatihan & 400 & 250 \\
\hline 9 & $\begin{array}{l}\text { Rasio Peningkatan Jumlah Anggota Satu } \\
\text { Tahun Terakhir }\end{array}$ & 200 & 150 \\
\hline 10 & Penghargaan Koperasi 3 Tahun Terakhir & 200 & 0 \\
\hline & Total & 10.000 & 2.400 \\
\hline
\end{tabular}

Sumber : Data Diolah, 2021

Berdasarkan tabel 1 diatas, maka hasil nilai aspek kelembagaan koperasi adalah sebesar 2.400 $\mathrm{X} 30 \%=720$. Setelah melakukan analisis diperoleh hasil bahwa untuk kinerja aspek kelembagaan koperasi mendapatkan nilai 2.400 dari skor maksimal 10.000. Indikator legalitas badan hukum memperoleh skor 500 dikarenakan parameter akte pendirian notaris, SK Pengesahan, telah diumumkan di dalam berita negara Republik Indonesia, telah diumumkan di dalam tambahan berita Negara RI serta memiliki NIlai Induk Koperasi (NIK) sudah terpenuhi semua; pada indikator partisipasi anggota persentase anggota yang aktif dalam membayar simpanan wajib dan aktif dalam bertransaksi mencapai nilai 200; pada indikator alat kelengkapan organisasi koperasi adanya kelengkapan struktur organisasi dan job description mencapai nilai 200; indikator rencana strategi sudah terpenuhi baik visi,misi, tujuan, sasaran, program dan kegiatan tahunan dilaksanakan serta adanya Rencana Anggaran Pendapatan Belanja Koperasi (RAPBK) sehingga diperoleh nilai 200; pada indikator Standar Operasional Prosedur SOP Kelembagaan dan organisasi, SOP usaha maupun SOP Keuangan sudah lengkap sehingga skor yang diperoleh 300; pada indikator Standar Operasional Manajemen sudah tersedianya aturan terkait dengan pengambilan keputusan dibidang 
kebijakan, wewenang pengeluaran uang maupun penentuan investasi pengembangan usaha sehingga diperoleh skor 300; pada indikator rapat anggota pertanggungjawaban pengurus dan pengawas dilaksanakan tepat waktu, pimpinan sidang berasal dari unsur anggota dan sudah mencapai keabsahan pengambilan keputusan; pada indikator pendidikan dan pelatihan hanya mencapai skor 250 dari 400 dikarenakan belum pernah mengirimkan anggotanya untuk mengikuti pendidikan anggota dan jumlah diklat karyawan yang berbasis kompetensi belum ada yang diteruskan dengan uji kompetensi; pada indikator rasio peningkatan jumlah angota satu tahun terakhir hanya $1-10 \%$ setahun sehingga diperoleh skor 150 dari 200; pada indikator penghargaan koperasi 3 tahun terakhir nilai 0 dikarenakan belum pernah mendapatkan penghargaan yang pernah diterima dari kementerian maupun luar kementerian koperasi dan UKM

\section{Kinerja KSU Patunggilan Ditinjau dari Aspek Usaha Koperasi}

Berdasarkan pedoman pemeringkatan koperasi apabila dinilai dari aspek Usaha koperasi KSU Patunggilan dapat dijelaskan dalam tabel berikut.

Tabel 2

Nilai dan Skor ditinjau dari Usaha Koperasi

\begin{tabular}{|c|l|c|c|}
\hline No & \multicolumn{1}{|c|}{ Indikator } & $\begin{array}{c}\text { Skor } \\
\text { Maksimal }\end{array}$ & $\begin{array}{c}\text { Nilai } \\
(\mathrm{N})\end{array}$ \\
\hline 1 & Legalitas Usaha & 100 & 100 \\
\hline 2 & $\begin{array}{l}\text { Keterikatan Aktivitas Usaha Anggota Dengan } \\
\text { Usaha Anggota Lain }\end{array}$ & 100 & 100 \\
\hline 3 & $\begin{array}{l}\text { Keterkaitan Usaha Anggota Dengan Usaha } \\
\text { Koperasi }\end{array}$ & 100 & 100 \\
\hline 4 & Peningkatan Volume Usaha & 100 & 50 \\
\hline 5 & Peningkatan Kapasitas Produksi/Jasa & 100 & 50 \\
\hline 6 & Peningkatan SHU & 100 & 50 \\
\hline & Total & 600 & 450 \\
\hline
\end{tabular}

Sumber : Data Diolah, 2021

Berdasarkan tabel 2 diatas, maka hasil nilai aspek Usaha Koperasi adalah sebesar 450 X 25\% $=112,5$. Setelah melakukuan analisis diperoleh hasil bahwa untuk kinerja aspek Usaha koperasi mendapatkan nilai 450 dari skor maksimal 600. Indikator legalitas usaha,keterikatan aktivitas usaha anggota dengan usaha anggota lain, keterkaitan usaha anggota dengan usaha koperasi, memperoleh skor maksimal yaitu masing-masing 100. Untuk indikator peningkatan volume usaha, peningkatan kapasitas produksi/jasa dan peningkatan SHU nilai masing-masing hanya 50 karena peningkatan omzet koperasi antara 5-10\% begitu pula persentase peningkatan kapasitas produksi/jasa dan persentase keuntungan yang dihasilkan dibanding tahun sebelumnya berkisar antara 5-10\%

\section{Kinerja KSU Patunggilan Ditinjau dari Aspek Keuangan Koperasi}

Berdasarkan pedoman pemeringkatan koperasi apabila dinilai dari aspek keuangan koperasi KSU Patunggilan dapat dijelaskan dalam tabel berikut.

Tabel 3

Nilai dan Skor ditinjau dari Keuangan Koperasi

\begin{tabular}{|c|l|c|c|}
\hline No & \multicolumn{1}{|c|}{ Indikator } & $\begin{array}{c}\text { Skor } \\
\text { Maksimal }\end{array}$ & $\begin{array}{c}\text { Nilai } \\
(\mathrm{N})\end{array}$ \\
\hline 1 & Struktur Permodalan & 100 & 80 \\
\hline 2 & $\begin{array}{l}\text { Kemampuan Penyediaan Dana Untuk Memenuhi } \\
\text { Kewajiban Yang Sudah Jatuh Tempo (Tingkat } \\
\text { Liquiditas) }\end{array}$ & 300 & 100 \\
\hline
\end{tabular}


Owner: Riset \& Jurnal Akuntansi

e-ISSN : 2548-9224 |p-ISSN : 2548-7507

Volume 5 Nomor 2, Agustus 2021

DOI : https://doi.org/10.33395/owner.v5i2.516

\begin{tabular}{|c|l|c|c|}
\hline 3 & Persentase Pelunasan Simpanan Wajib Anggota & 100 & 100 \\
\hline 4 & Total Kewajiban Jangka Pendek Terhadap Aset & 200 & 200 \\
\hline 5 & $\begin{array}{l}\text { Kemampuan Koperasi Untuk Memenuhi } \\
\text { Kewajibannya (Solvabilitas) }\end{array}$ & 100 & 100 \\
\hline & \multicolumn{1}{|l}{$\begin{array}{l}\text { Rasio Laba Bersih Terhadap Asset Investasi } \\
\text { (Return On Investment/ROI) }\end{array}$} & 100 & 0 \\
\hline 7 & Penambahan Aset & 100 & 0 \\
\hline 8 & Audit Kantor Akuntan Publik (KAP) & 200 & 100 \\
\hline 9 & Keberlanjutan Usaha & 160 & 110 \\
\hline & Total & 1.360 & 790 \\
\hline
\end{tabular}

Sumber : Data Diolah, 2021

Berdasarkan tabel 3 diatas, maka hasil nilai aspek keuangan koperasi adalah sebesar $790 \mathrm{X}$ $25 \%=197,5$. Setelah melakukuan analisis diperoleh hasil bahwa untuk kinerja aspek keuangan koperasi mendapatkan nilai 790 dari skor maksimal 1.360. Indikator struktur permodalan dengan parameter rasio antara modal sendiri dengan modal pinjaman antara 20-50\% sehingga diperoleh skor 80 dari 100. Untuk indikator kemampuan penyedia dana untuk memenuhi kewajiban yang sudah jatuh tempo (tingkat likuiditas) dengan parameter cash ratio $<5 \%$ diperoleh nilai 50 dari 100 , acid test ratio $<10 \%$ mendapatkan nilai 50 dari 100 dan current ratio nilai 0 karena $<110 \%$. Pada indikator persentase pelunasan simpanan wajib dengan parameter persentase peningkatan simpanan wajib secara riil dibandingkan dengan simpanan wajib yang seharusnya ada pada kriteria $10-20 \%$ sehingga diperoleh nilai 50 dari 100. Pada indikator total kewajiban jangka pendek terhadap aset mendapatkan total nilai 200 terdiri dari parameter persentase kewajiban jangka pendek terhadap aset sebesar $<30 \%$ dan persentase hutang dagang $<=10 \%$. Pada indikator kemampuan koperasi untuk memenuhi kewajibannya memiliki nilai 0 dikarenakan persentase aset dengan kewajiban $<110 \%$. Indikator rasio laba bersih terhadap aset investasi memiliki nilai 0 dikarenakan persentase keuntungan terhadap investasi/aset sebesar $<10 \%$. Pada indikator penambahan aset memiliki nilai 0 karena tidak ada penambahan aset. Pada indikator audit kantor akuntan publik memiliki nilai 100 dari nilai maksimal 200, nilai 100 untuk parameter kelengkapan laporan keuangan karena pada laporan RAT unsur laporan keuangan lengkap sedangkan untuk parameter opini hasil audit KAP nilainya 0 karena laporan keuangan tidak di audit oleh KAP. Pada indikator keberlanjutan usaha mempunyai nilai 110 dari nilai 160 dengan parameter ketentuan rasio antar pendapatan operasional dengan biaya operasional antara 100-110\% dengan nilai 50 skor yang baik adalah jika melebihi $110 \%$, KSU Patunggilan menjalin kemitraan.dengan badan hukum lain sehingga diperoleh nilai 60.

Tabel 4

Nilai dan Skor ditinjau dari Aspek Manfaat Koperasi Bagi Anggota

\begin{tabular}{|c|l|c|c|}
\hline No & \multicolumn{1}{|c|}{ Indikator } & $\begin{array}{c}\text { Skor } \\
\text { Maksimal }\end{array}$ & $\begin{array}{c}\text { Nilai } \\
(\mathrm{N})\end{array}$ \\
\hline 1 & Peningkatan Penghasilan Anggota & 200 & 0 \\
\hline 2 & $\begin{array}{l}\text { Menawarkan Harga Barang Dan Jasa Kepada } \\
\text { Anggota Yang Lebih Murah }\end{array}$ & 100 & 100 \\
\hline 3 & Menumbuhkan Motif Berusaha Anggota & 100 & 50 \\
\hline 4 & Menumbuhkan Sikap Jujur Dan Terbuka & 200 & 100 \\
\hline 5 & $\begin{array}{l}\text { Pemberian Layanan Koperasi Diluar Aktivitas } \\
\text { Usaha }\end{array}$ & 100 & 100 \\
\hline & Total & 700 & 350 \\
\hline
\end{tabular}

Sumber : Data Diolah, 2021

Berdasarkan tabel 4 diatas, hasil nilai aspek manfaat koperasi bagi anggota adalah sebesar 350 $\mathrm{X} 10 \%=35$. Setelah melakukan analisis diperoleh hasil bahwa untuk kinerja aspek manfaat 
koperasi bagi anggota mendapatkan nilai 350 dari skor maksimal 700. Indikator peningkatan penghasilan anggota nilai 0 dikarenakan parameter rata-rata SHU yang diterima per anggota per tahun $<12 \mathrm{X}$ UMR setempat dan tidak ada jumlah anggota yang usahanya naik kelas baik dari mikro kecil atau kecil menengah. Pada indikator menawarkan harga barang dan jasa kepada anggota yang lebih murah KSU Patunggilan memperoleh nilai 100 karena sudah dilakukan. Jumlah wirausaha baru yang ditumbuhkan oleh koperasi berkisar 5-20 orang. Koperasi juga telah melakukan publikasi laporan keuangan lebih dari 4 kali karena dari sejak berdiri tahun 2003 sedangkan jumlah publikasi informasi perubahan harga barang dan jasa yang disediakan koperasi tidak ada karena koperasi tidak menyediakan barang dan menerima jasa sehingga nilainya 0

Tabel 5

Nilai dan Skor ditinjau dari Aspek Manfaat Koperasi Terhadap Masyarakat

\begin{tabular}{|c|l|c|c|}
\hline No & \multicolumn{1}{|c|}{ Indikator } & $\begin{array}{c}\text { Skor } \\
\text { Maksimal }\end{array}$ & $\begin{array}{c}\text { Bobot } \\
\text { (B) }\end{array}$ \\
\hline 1 & Penyerapan Tenaga Kerja & 100 & 0 \\
\hline 2 & $\begin{array}{l}\text { Jumlah Layanan Koperasi Yang Dapat } \\
\text { Dinikmati Masyarakat }\end{array}$ & 100 & 0 \\
\hline 3 & Penurunan Angka Kemiskinan & 200 & 110 \\
\hline & Total & 400 & 110 \\
\hline
\end{tabular}

Sumber : Data Diolah, 2021

Berdasarkan tabel 4 diatas, hasil nilai aspek manfaat koperasi terhadap masyarakat sebesar $110 \times 10 \%=11$. Setelah melakukan analisis diperoleh hasil bahwa untuk kinerja aspek manfaat koperasi bagi anggota mendapatkan nilai 110 dari skor maksimal 400. Indikator penyerapan tenaga kerja nilai 0 dikarenakan parameter jumlah tenaga kerja koperasi kurang dari 5 orang begitu pula jumlah layanan koperasi yang dapat dinikmati masyarakat dengan parameter dampak keberadaan koperasi bagi masyarakat dibidang infrastruktur, transportasi, penerangan, air bersih dan kerohanian bernilai 0. Pada indikator penurunan angka kemiskinan dengan parameter persentase dana pembangunan daerah kerja (CSR) terhadap lingkungan hanya 1-2,5\% sehingga bernilai 60 dari skor maksimal 100 begitu pula pada parameter kontribusi gerakan koperasi di daerah yang bersangkutan terhadap PDRB kurang dari 0,001\% sehingga nilainya hanya 50 dari 100.

\section{PEMBAHASAN \\ Penilaian pemeringkatan Koperasi KSU Patunggilan ditinjau dari Aspek Kelembagaan Koperasi}

Berdasarkan analisis yang telah dilakukan, kinerja aspek kelembagaan koperasi mendapatkan skor 720 dari skor maksimal 1.000. Jika dilihat dari indikator ketercapaiannya sebesar $72 \%$ dapat dilihat dari aspek legalitas badan hukum dinilai "baik", akan tetapi pencapain ini masih belum maksimal dikarenakan koperasi dalam 3 tahun terakhir tidak mendapatkan penghargaan. Pendidikan dan penelitian serta rasio peningkatan jumlah anggota satu tahun terakhir pertambahannya kurang maksimal sehingga mendapatkan skor yang rendah. Rencana strategis,koperasi setahun sampai 3 tahun kedepan sebaiknya ada agar memudahkan menilai kinerja koperasi.

\section{Penilaian pemeringkatan Koperasi KSU Patunggilan ditinjau dari usaha koperasi}

Berdasarkan analisis yang telah dilakukan, aspek usaha koperasi yang dinilai bagus mendapatkan skor 112,5 dari skor maksimal sebesar 150. Rasio ketercapaiannya sebesar $75 \%$, dinilai "baik", akan tetapi masih ada kekurangan dalam peningkatan volume usaha, peningkatan kapasitas produksi/jasa dan peningkatan SHU. Omzet tahun 2020 sebesar 202.270.010 sedangkan pada tahun sebelumnya yaitu tahun 2019 sebesar Rp. 93.570.683, hal ini terdapat peningkatan yang cukup baik yakni sebesar 53,74\% skor tersebut berada di posisi antara 5-10\%, untuk skor maksimal dinilai 100 apabila prosentase berkisar $>10 \%$. 


\section{Penilaian pemeringkatan Koperasi KSU Patunggilan ditinjau dari keuangan koperasi.}

Berdasarkan analisis yang telah dilakukan, aspek keuangan koperasi dinilai bagus mendapatkan skor 197,5 dari skor maksimal sebesar 340. Rasio ketercapaiannya sebesar 58\%, pada struktur permodalan modal sendiri lebih besar daripada modal pinjaman hal ini kemungkinan besar modal sendiri belum terdistribusi dengan baik kepada anggota melalui pemberian pinjaman, sehingga modal mengendap sebaiknya modal tersebut diputar untuk kepentingan anggota. Pada tabel 3 yang perlu diperhatikan yaitu pada indikator rasio laba bersih terhadap asset investasi dan penambahan aset yang memiliki nilai 0 hal ini disebabkan oleh koperasi tidak menambah aset pada tahun 2020.

\section{Penilaian pemeringkatan Koperasi KSU Patunggilan ditinjau dari aspek manfaat bagi koperasi}

Berdasarkan analisis yang telah dilakukan pada tabel 4 diatas, aspek manfaat bagi koperasi mendapatkan skor 35 dari skor maksimal sebesar 70. Rasio ketercapaiannya sebesar 50\%, masih ada kekurangan dalam peningkatan penghasilan anggota,kurang dari 12X UMR dan belum ada anggota yang memiliki usaha naik kelas dari mikro ke kecil atau dari kecil ke menengah. Dengan kehadiran koperasi diharapkan dapat menumbuhkan motif berwirausaha anggota, pada KSU Patunggilan sebaiknya memberikan lebih banyak memberikan stimulus modal kepada para anggota yang memiliki usaha agar naik kelas sehingga bisa tumbuh wirausaha baru.Meskipun koperasi serba usaha tetapi KSU Patunggilan tidak memiliki unit pertokoan sehingga untuk parameter jumlah publikasi informasi perubahan harga barang dan jasa yang disediakan koperasi tidak ada.

\section{Penilaian pemeringkatan Koperasi KSU Patunggilan ditinjau dari aspek manfaat koperasi terhadap masyarakat.}

Berdasarkan analisis yang telah dilakukan pada tabel 5 diatas, aspek manfaat bagi koperasi mendapatkan skor 11 dari skor maksimal sebesar 40. Rasio ketercapaiannya sebesar 27,5\%, terhitung kurang begitu baik karena dalam hal ini KSU Patunggilan tidak memiliki tenaga kerja atau karyawan koperasi sehingga nilainya 0 termasuk koperasi belum adanya dampak keberadaan koperasi bagi masyarakat. Sebaiknya koperasi memiliki peran kepada masyarakat dengan memberikan CSR kepada lingkungan.

\section{KESIMPULAN}

Berdasarkan hasil akumulasi skor penilaian kinerja lima aspek yang telah dilakukan, KSU Patunggilan mendapatkan skor 1.076 dari total skor maksimal 1.600. Menurut Peraturan Menteri Koperasi dan Usaha Kecil dan Menengah Republik Indonesia Nomor 21/Per/M.KUKM/IX/2015 Tentang Pemeringkatan Koperasi skor tersebut berada pada rentang skor 1.000 sampai dengan 1.200 sehingga KSU Patunggilan masuk dalam koperasi dengan kualifikasi "Berkualitas" dengan predikat AAB. Keterbatasan penelitian ini hanya dilakukan pada tahun 2020 setidaknya 5 tahun pemeringkatan sehingga dapat dijadikan evaluasi dan mengetahui perkembangan kinerja koperasi dalam 5 tahun apakah menunjukkan perubahan yang semakin baik atau menurun kinerjanya. Bagi peneliti selanjutnya sebaiknya penelitian tidak hanya pada satu koperasi saja melainkan seluruh koperasi dibawah naungan Dinas Koperasi dan UMTK se-Kabupaten Mojokerto

\section{UCAPAN TERIMA KASIH}

Terimakasih kepada Lembaga Penelitian dan Pengembangan (LPPM) Universitas Islam Kadiri. Penelitian ini dapat terwujud karena adanya hibah internal kampus

\section{DAFTAR PUSTAKA}

Arifin, \& Halomoan. (2001). Koperasi Teori dan Praktek. Penerbit Erlangga.

Asdhiwitanto, R., Dwiatmanto, \& Azizah, D. F. (2015). PENILAIAN KINERJA KESEHATAN KOPERASI BERDASARKAN SURAT KEPUTUSAN MENTERI KOPERASI DAN USAHA KECIL MENENGAH NOMOR 35.3/Per/M.KUKM/X/2007. Jurnal Administrasi 
Owner: Riset \& Jurnal Akuntansi

e-ISSN : 2548-9224 |p-ISSN : 2548-7507

Volume 5 Nomor 2, Agustus 2021

Bisnis (JAB), 28(2). https://media.neliti.com/media/publications/86471-ID-penilaian-kinerjakesehatan-koperasi-ber.pdf

Bagus, I., Bimantara, W., Suwendra, I. W., \& Meitriana, M. A. (2019). Analisis Kinerja Koperasi Dengan Metode Pemeringkatan ( Studi Kasus Pada Ksu Nirmala Tirta ). 11(2).

Indonesia, M. K. dan U. K. M. R. (2015). PERATURAN MENTERI KOPERASI DAN USAHA KECIL DAN MENENGAH REPUBLIK INDONESIA NOMOR 21/Per/M.KUKM/IX/2015 TENTANG PEMERINGKATAN KOPERASI.

Kemenkop. (2012). UNDANG-UNDANG TENTANG PERKOPERASIAN.

Kemenkop. (2021). Data Koperasi. https://www.kemenkopukm.go.id/datakoperasi/?EdJI2GnvrG9UI9YDm2u6AhgVLylTBL6GpGOiN2U48TPHTnL6f5

Menkop. (2015). Pemeringkatan Koperasi.

Rahman, A. (2018). Pemeringkatan koperasi dalam konteks pemberdayaan koperasi. Prosiding Seminar Nasional Multidisiplin Ilmu Universitas Asahan, November, 250-259. http://jurnal.unej.ac.id/index.php/bisma/article/download/53/30

Widagdo, W. T. (2013). PEMERINGKATAN KOPERASI MAHASISWA UNIVERSITAS NEGERI YOGYAKARTA [Universitas Negeri Yogyakarta]. https://eprints.uny.ac.id/17758/1/SKRIPSI FULL_WISNU TRI WIDAGDO_10404241047.pdf 